\title{
Efficiency of the goalkeepers in the women's World Handball Championship in Germany 2017
}

\section{Eficácia dos goleiros no Campeonato Mundial de Handebol feminino Alemão de 2017}

\section{Manuel Gómez-López}

(D) https://orcid.org/0000-0002-4595-3994

Salvador Angosto ${ }^{1}$

(D) https://orcid.org/0000-0001-7281-794X

Antonio Antúnez $z^{2}$

(D) https://orcid.org/0000-0002-7451-4448

Abstract - The performance of goalkeepers can predict the final ranking of teams in tournaments. The aim of the study was to examine the percentages of goalkeepers of different national teams, according to the position on the field from which the pitch was taken, the location of the pitch in the goal and the ranking of the game. To this end, a documentary study based on the data collected by the International Handball Federation was carried out with 24 national teams that took part in the last absolute handball world championship (Germany 2017). The sample consisted of 7606 pitches made in 83 matches. The results showed that the highest percentage of saves was obtained with shots taken from the 9 meters and to the central and middle zone of the goal, and the lowest with throws in fast-breaks and to the lower and lateral areas of the goal. There were no significant differences in the variables analyzed according to the game ranking, except in pitching zone 1.

Key words: Efficiency; Gender analysis; Indicators; Sports performance

Resumo - $O$ desempenho do goleiro pode prever a classificação final das equipas em torneios. $O$ objetivo do estudo foi examinar as porcentagens de defesas feitas por goleiros de diferentes seleçôes, de acordo com a posição no campo de onde o chute foi feito, a localização do chute no gol e o ranking do jogo. Para tal, foi realizado um estudo documental baseado em dados recolbidos pela Federação Internacional de Handebol com 24 equipes que participaram no último Campeonato do Mundo de Handebol absoluto (Alemanha 2017). A amostra consistiu em 7606 lances feitos em 83 partidas. Os resultados mostraram que a maior porcentagem de defesas foi obtida a partir dos chutes de 9 metros e da zona central e média do gol, e a menor porcentagem de defesas a partir dos chutes de contra-ataque e das zonas baixa e lateral do gol. Não houve diferenças significativas nas variáveis analisadas de acordo com o ranking do jogo, exceto na zona 1 de arremesso.

Palavras-chave: Análise de gênero; Desempenho esportivo; Eficiência; Indicadores.
1 University of Murcia. Faculty of Sport Sciences. Department of Physical Activity and Sport. Santiago de la Ribera (Murcia). Spain.

2 University of Extremadura. Faculty of Sport Sciences. Department of Didactics of Musical, Plastic and Corporal Expression. Cáceres. Spain

Received: March 11, 2020 Accepted: October 20, 2020

How to cite this article Gómez-López M, Angosto S, Antúnez A. Efficiency of the goalkeepers in the women's World Handball Championship in Germany 2017. Rev Bras Cineantropom Desempenho Hum 2020, 22:e72115. DOl: http://dx.doi.org/10.1590/19800037.2020v22e72115

Copyright: This work is licensed under a Creative Commons Attribution 4.0 International License. 


\section{INTRODUCTION}

In team sports and specifically in handball, different lines of research have been opened, among which the study of competition and analysis of team performance through the use of game statistics from national and international competitions stands out ${ }^{1-10}$.

Focusing on the object of study, it should be noted that the specific position of the goalkeeper stands out in handball for its importance to other players, given that in this cooperation-opposition invasion game with ball and a fixed goal each action ends with a shot or a game action close to the opponent's goal so that their actions and, more specifically, their effectiveness against the opponent's shots is a very important performance variable for their team ${ }^{11-12}$ and frequently a decisive one ${ }^{13}$.

The literature on handball has shown the importance of the goalkeeper's efficiency variable as it is related to the final ranking of the teams, both in high-level international championships ${ }^{4,14-15}$ and in regular leagues ${ }^{13}$. It has recently been shown that active defense, technical errors in attack and overall goalkeeper performance appear to be the main factors separating winning teams from losing teams in close matches ${ }^{16}$.

Despite this assessment, very few studies have been conducted so far on the performance characteristics of elite female goalkeepers ${ }^{17}$ at the Olympics, World Championships and European Championships. Moreover, within the field of sports training, attention to the figure of the goalkeeper is either non-existent or anecdotal and is often even based on intuitive notions ${ }^{18}$. Therefore, a more detailed analysis of their performance during a World Championship could improve training methods for this specific position and help us to better understand its relative contribution to success in matches and tournaments. Therefore, considering this lack of data on elite goalkeepers, the objectives of the present study was to determine the total percentage of stops (effectiveness) of the goalkeepers belonging to the 24 national teams that competed in the 2017 World Championship in Germany, as well as effectiveness in terms of the position on the field from which the shot was taken and the location of the shot in the goal. A further objective was to discover the existing differences in terms of the ranking in which the different teams played.

\section{METHODS}

\section{Sample}

All the goalkeepers who competed in the 2017 Women's World Handball Championship in Germany participated in this study. The sample consisted of 7606 shots made by the players of the 24 participating teams during 83 matches. Of the total number of matches played in the Championship, only one was excluded because it could not be analyzed as the information was not available on the International Handball Federation (IHF) website. Table 1 shows the distribution of shots and the final position occupied by each national team. 
Table 1. Distribution of throws by national team

\begin{tabular}{llll}
\hline National Team & Total Throws & National Team & Total Throws \\
\hline 1. France & 383 & 13. South Korea & 281 \\
2. Norway & 366 & 14. Slovenia & 278 \\
3. Netherlands & 417 & 15. Hungary & 236 \\
4. Sweden & 433 & 16. Japan & 276 \\
5. Russia & 336 & 17. Poland & 376 \\
6. Denmark & 290 & 18. Brazil & 307 \\
7. Montenegro & 308 & 19. Angola & 313 \\
8. Czech Republic & 344 & 20. Camerún & 337 \\
9. Serbia & 272 & 21. Paraguay & 328 \\
10. Romania & 245 & 22. China & 338 \\
11. Spain & 239 & 23. Argentina & 345 \\
12. Germany & 228 & 24. Tunisia & 330 \\
Total Throws $=7606$ & & & \\
\hline
\end{tabular}

\section{Variables}

The variables used to observe the effectiveness of the goalkeepers of the national teams that participated in the last Women's World Cup were grouped as follows, in line with Prudente's indicator ranking ${ }^{19}$ :

- General information on the match: number of total goals conceded, number of total possessions by the opposing team, number of missed shots by the opponent, total saves per match, number of total shots received and taken by the goalkeeper and total efficiency of the goalkeeper.

- Information about the shots according to the location in the goal (Technical Variables): number of saves and shots received according to the goal area.

- Information on the shots according to the position in the field from which they were taken (Tactical Variables): number of saves and shots received according to the position from the $6 \mathrm{~m}, 7 \mathrm{~m}, 9 \mathrm{~m}$, wings, in fast-breaks and breakthroughs.

\section{Procedures}

The procedure followed to carry out the investigation was to enter the data from the Women's World Championships available on the official website of the International Handball Federation (www.ihf.info). The template sheets of each participating team were downloaded for each championship, as well as the statistics sheets for the results of all the matches in each championship. Once all the statistical templates had been downloaded, they were registered from February 14th to April 9th, 2019 through a form in the University of Murcia's Survey tool. Finally, the data was analyzed and the report was written.

\section{Data analysis}

The data were analyzed with SPSS Statistics 22.0. Frequencies and percent- 
ages were calculated for the categorical variables, and minimum, maximum, mean and standard deviation were obtained for the continuous variables. The Student $t$ test was carried out to observe the existence of differences in the statistics according to ranking. The significance level was established at a value of $\mathrm{p} \leq .05$.

\section{RESULTS}

The results of the general match data are shown in Table 2 . The data indicated that the teams conceded an average of $26.10 \pm 5.9$ goals in $56.01 \pm 5.1$ possessions of the opposing team. The total number of shots received per game was $45.82 \pm 5.8$. The goalkeepers made $11.19 \pm 3.9$ saves from $37.29 \pm 5.5$ shots with a $30.30 \%$ save effectiveness.

Table 2. Comparative statistics of the data according to the ranking.

\begin{tabular}{lccccccc}
\hline & \multicolumn{2}{c}{ Total } & \multicolumn{2}{c}{ Ranking 1 } & \multicolumn{2}{c}{ Ranking 2 } & Value \\
\cline { 2 - 7 } & $\mathrm{M}$ & S.D. & $\mathrm{M}$ & S.D. & $\mathrm{M}$ & S.D. & $\mathrm{p}$ \\
\hline Total goals received & 26.10 & 5.9 & 23.95 & 5.5 & 28.46 & 5.5 & $.000^{*}$ \\
Number of attacks produced by the rival & 56.01 & 5.1 & 54.99 & 5.2 & 57.15 & 4.9 & $.006^{*}$ \\
Total throws received & 45.82 & 5.8 & 44.38 & 6.0 & 47.41 & 5.2 & $.001^{*}$ \\
Opponent's failed throws & 8.48 & 3.3 & 8.80 & 3.4 & 8.12 & 3.3 & .192 \\
Total saves & 11.19 & 3.9 & 11.61 & 4.1 & 10.73 & 3.5 & .147 \\
Throws received by the goalkeeper & 37.29 & 5.5 & 35.56 & 5.3 & 39.19 & 5.2 & $.000^{*}$ \\
Total Goalkeeper Efficiency & 30.30 & 10.6 & 32.77 & 11.3 & 27.58 & 9.2 & $.001^{*}$ \\
\hline
\end{tabular}

Note: * $p$ value $\leq, 05$

The teams were then classified according to the Ranking, i.e. according to the position achieved in the Championship. For this purpose, Ranking 1 ( $\mathrm{n}=87$ matches) included all those teams that played the qualifying round for the title (Positions 1-12), while Ranking 2 ( $\mathrm{n}=79$ matches) included all the teams that played the President's Cup (Positions 13-24). The results showed that the lowest-ranked teams conceded about 4 more goals and more shooting opportunities than the best teams. The best teams caused a higher error rate in the rival team's shooting (Ranking $1=8.80 \pm 3.4$ : Ranking $2=8.12 \pm 3.3$ ) and made a greater number of saves (Ranking $1=11.61 \pm 4.1$; Ranking $2=10.73 \pm 3.5$ ). However, no significant differences were found for these variables. The goalkeepers of the best teams were more effective in saves $(M=32.77 \pm 11.3)$ than those that played in President's Cup $(\mathrm{M}=27.58 \pm 9.2)$. Furthermore, there were statistically significant differences in the variables of goals conceded, opponent's attacks, total shots received, effectiveness and shots saved by the goalkeeper $(\mathrm{p} \leq .05)$.

The results of goalkeepers' effectiveness according to the shooting zone (Table 3) showed that they were more successful with shots from more than nine meters $(M=43.81 \pm 18.7 \%)$, followed by shots from the corners of the playing area $(M=36.74 \pm 25.5 \%)$ and shots from six meters $(M=31.48 \pm 17.7 \%)$. Shots made after a breakthroughs or from a penalty (seven meters) were those goalkeepers found hardest to save and had the lowest effectiveness 
of all the analyzed zones with percentages of $15.68 \pm 23.4$ and $19.05 \pm 22.1$ respectively. According to the ranking, it was observed that in general the goalkeepers who played the qualifying rounds for the title had better effectiveness than the goalkeepers of the other teams. As in the global results, the best effectiveness was obtained in the saves from the shots made from nine meters, followed by those from the wings and six meters in both groups. The worst effectiveness in saves was obtained in penalty or breakthroughs shots. Finally, it must be emphasized that no statistically significant differences were found in any of the variables, although in the effectiveness of shots from six and seven meters there existed a strong tendency towards significance.

Table 3. Effectiveness of the goalkeepers according to the zone from which the throw is executed and according to the ranking

\begin{tabular}{lccccccc}
\hline \multirow{2}{*}{ Variables } & \multicolumn{3}{c}{ Total } & \multicolumn{3}{c}{ Ranking 1 } & \multicolumn{2}{c}{ Ranking 2 } & $\mathrm{p}$ \\
\cline { 2 - 7 } & $\mathrm{M}$ & S.D. & $\mathrm{M}$ & S.D. & $\mathrm{M}$ & S.D. & value \\
\hline Percentage of 6m shots saves & 31.48 & 17.7 & 31.58 & 18.4 & 26.77 & 15.9 & .075 \\
Percentage of extreme shots saves & 36.74 & 25.5 & 38.03 & 24.6 & 33.57 & 22.4 & .226 \\
Percentage of 9m shots saves & 43.81 & 18.7 & 42.90 & 19.2 & 38.90 & 20.5 & .201 \\
Percentage of 7m shots saves & 19.05 & 22.1 & 21.56 & 22.5 & 15.91 & 20.2 & .095 \\
Percentage of fast-breaks shots saves & 22.37 & 26.5 & 21.85 & 24.8 & 19.11 & 21.3 & .460 \\
Percentage of breakthroughs shots saves & 15.68 & 23.4 & 18.18 & 24.2 & 12.90 & 21.3 & .150 \\
\hline
\end{tabular}

Figure 1 shows the percentage of effectiveness according to shooting zone in general and according to the ranking obtained as well. The highest effectiveness was obtained in the middle zone of the goal with percentages ranging from $48.65 \%(\mathrm{Z} 4)$ to $70.15 \%(\mathrm{Z} 5)$ followed by the upper zone of the goal with an effectiveness range between $22.11 \%(Z 3)$ and $40.42 \%$ (Z2) and finally its lower zone where the goalkeepers had more difficulty in stopping the shots $(Z 7=19.10 \%$ to $Z 8=33.74 \%)$. If we focus on the sides of the goal the results showed that the goalkeepers obtained similar percentages of effectiveness on both left and right side shots. If we compare the results according to the ranking it was observed that the best teams had better effectiveness in all goal areas except $Z 2$ and Z8. The goalkeepers who played the qualifying matches for the title (Ranking 1) had greater effectiveness in the middle zone of the goal with percentages above $50 \%$ followed by the high zone with effectiveness percentages that varied from $24.59 \%$ (Z3) to $39.29 \%$ (Z2) while in the low zone there were percentages below $32.85 \%$ (Z8) and a minimum of $21.41 \%(\mathrm{Z} 7)$. Also the best goalkeepers had slightly better percentages of stopping shots on the right side of the goal. Regarding the goalkeepers who played the President's Cup (Ranking 2) they also obtained the highest effectiveness against shots to the middle zone of the goal ( $Z 6=46.07 \%$ to $Z 5=65.38 \%)$. followed by the high zone ( $Z 1=18.23 \%$ to $Z 2=41.71 \%)$. and the low zone. with minimum percentages in $Z 7$ of only $16.57 \%$ effectiveness. Like the best goalkeepers the goalkeepers of the teams in the lower zone of the 
ranking were slightly more effective in saves on the right zone of the goal than the left. In Z1 there were statistically significant differences when comparing the goalkeepers according to the ranking $(\mathrm{p} \leq .05)$ and a high tendency to significance in $Z 7(\mathrm{p}=.085)$ and $Z 9(\mathrm{p}=.073)$.
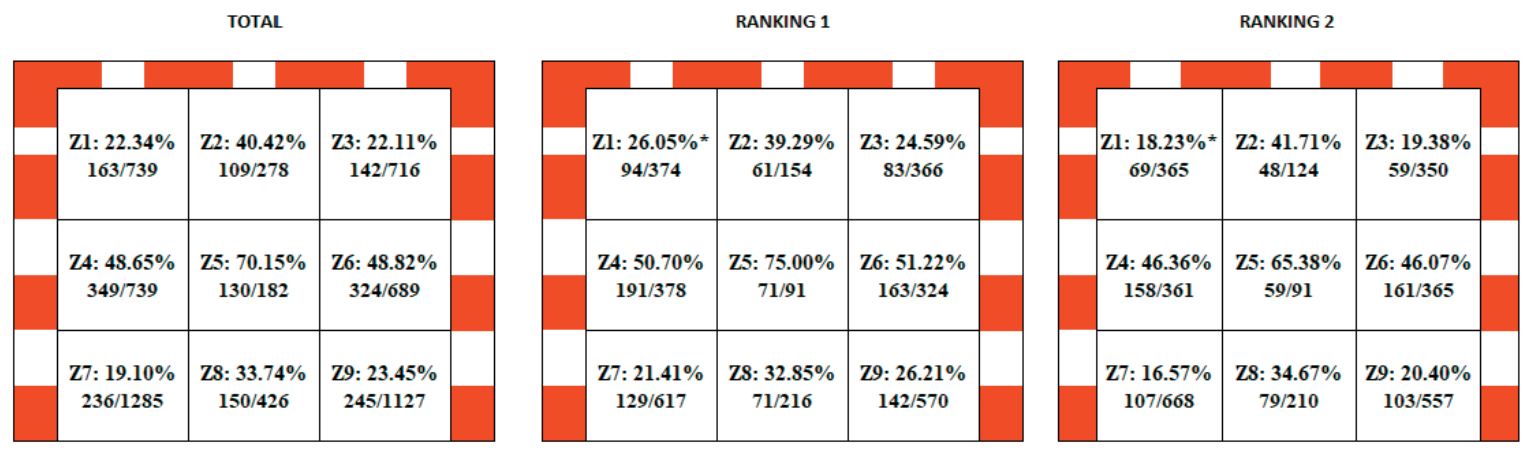

Figure 1. Effectiveness of goalkeepers according to goal throwing zone and ranking

\section{DISCUSSION}

The percentage of effectiveness of goalkeepers in the Championship analyzed was $30.30 \%$ which is slightly lower than that found in other international competitions such as $33 \%$ in the 2014 ODESUR and $31 \%$ in the 2014 Pan American Championship ${ }^{15}$. This result is similar to that found in the 2015 World Championship which had an effectiveness rate of $30.3 \%{ }^{20}$. It is slightly lower than that provided by Bilge ${ }^{2}$ which found no statistically significant differences when comparing the World Championships (34.7\%) and European Championships (33.5\%) during the 2004-2010 period. By contrast. Antón ${ }^{21}$ considers that goalkeeper performances are positive and relevant based on an efficiency of 33\%.

Regarding the ranking in which the different teams participated the results showed that the goalkeepers of the best teams were more effective than those who played in the President's Cup.

The percentage of saves and their relation to the shooting player's position are usually presented as the main indices of goalkeeper performance analysis ${ }^{2.17 .22}$. The results of the study showed that the percentage of saves was higher for shots from nine meters followed by those from the wings six meters fast-breaks seven meters and breakthroughs. These results partially coincide with those previously found by Espina-Agulló et al. ${ }^{4}$ with goalkeepers of a similar level although the classification used by these authors was different. Likewise the results also coincide with the results provided by Hansen et al. ${ }^{17}$ with a sample of goalkeepers belonging to 24 teams that participated in the 2015 world championships.

In the majority of the studies consulted. the goalkeeper's effectiveness was higher when faced with shots from a distance of nine meters; these results may be due to the fact that from this distance the goalkeeper has more reaction time to make the save $\mathrm{e}^{23}$ or because the shot most used by the teams from this distance is a jump throw and most goalkeepers are 
usually very used to this type of shot ${ }^{24}$ without forgetting of course the effectiveness of the defense-goalkeeper collaboration ${ }^{25}$.

By contrast one of the lowest percentages of effectiveness was obtained in the case of shots made in fastbreaks that is to say shots made on the run towards the goalkeeper and without defenders. These results coincide with those provided by Blanco ${ }^{26}$ in his observational analysis of the Spanish junior handball team's shots since he indicated that the highest percentage of success was in those made in fast-breaks. According to the literature the success of fast-breaks and the lack of goalkeeper success against them may be due to the fact that a high percentage of these shots are jump shots ${ }^{26}$ especially from the central area thus obtaining the best shooting angle with respect to the goal ${ }^{27}$ which makes it difficult for the goalkeeper to make a save. In addition to this the difficulty resulting from the distance from which the shot is taken on the fast-breaks must also be added since the results of different studies have shown that most shots are taken in the same area less than six meters from the goal thus fulfilling the principle of maximum depth search for the shot [9]. Other studies however showed that most of these shots were taken between six and nine meters from the goal ${ }^{1.26}$.

With regard to the results obtained according to ranking it was shown that the percentage of saves was higher in the goalkeepers in Ranking 1 i.e. the best rated. These results are similar to those found by Sáez et al. ${ }^{10}$ which showed that the losing teams in the King's Cup had more saves on fastbreaks than the winning teams.

The results found in relation to the effectiveness of seven-meter shots according to the ranking show that the goalkeepers of the best teams were more effective than the teams in Ranking 2. These results coincide with those provided by Sáez et al. ${ }^{28}$ with players in training where it was shown that the shots from seven meters differentiated the winning teams from the losers the latter being more effective in the winning teams. This lower effectiveness of the losing teams may be due to lower technical quality and greater perceived anxiety of the players ${ }^{29}$.

The results showed that both the middle and central areas of the goal are where the goalkeepers achieve the highest percentages of saves. This result may be due to the fact that goalkeepers occupy the central areas of the goal with their bodies when taking the base position in the goal. It is also worth mentioning that in the data obtained in this study the area with the lowest saving was the lower area both to the left and to the right of the goalkeeper. The results provided by Hansen et al. ${ }^{17}$ regarding the goalkeepers who participated in the Men's World Championship in Qatar 2015 reflected high rates of saves on both the right and left and especially in the center of the goal. More specifically the highest percentages of saves were found in the right central zone. According to these authors these results can be explained by the skill of the goalkeepers.

With regard to the ranking although the percentages are higher for the goalkeepers in Ranking 1 there are no differences in the pattern of saves of the goalkeepers of the best and worst classified teams. 
The main limitation of the work is the scant existing bibliography that has analyzed the same variables that are the object of study and that which exists is quite dated. As for the strengths of the study it should be pointed out that new variables have been introduced since up to now the percentage of saves according to the location of the shot in the nine goal areas has not been examined.

\section{CONCLUSIONS}

The results obtained in the study allow us to establish the following conclusions: a) The highest percentage of saves was obtained when the shots came from nine meters and to the central and middle zone of the goal and the lowest one was observed when shooting on fast-breaks and to the low and lateral zones of the goal and. b) There are no significant differences in the variables analyzed according to the ranking of the game except in the shooting zone 1.

\section{COMPLIANCE WITH ETHICAL STANDARDS}

\section{Funding}

This research did not receive any specific grant from funding agencies in the public commercial or not-for-profit sectors.

\section{Ethical approval}

This research is in accordance with the standards set by the Declaration of Helsinki

\section{Conflict of interest statement}

The authors have no conflict of interests to declare.

\section{Author Contributions}

Developed and coordinated the study: MG-L; Helped in data collection: SAS; Data analysis: SAS; Wrote the article: MG-L. SAS and AAM; Critical review of the article: MG-L. SAS and AAM.

\section{REFERENCES}

1. Ávila FM. Aplicación de un sistema observacional para el análisis del lanzamiento en balonmano en el Mundial de Francia 2001 [Application of an observational system for the analysis of handball launches at the 2001 World Cup in France]. Apunts Educ Fís Deporte 2003;71(1):100-108.

2. Bilge M. Game Analysis of Olympic. World and European Championships in Men's Handball. J Hum Kinet 2012;35(1):109-118.

3. Botejara J, Punales L, Gonzalez A, Ruy E, Trejo A. Analysis of the completion of the possession of the ball in handball. Study of the men's world championship 2011. Rev Universitaria Educ Fís Deporte 2012;(5):6-14.

4. Espina-Agulló JJ, Pérez-Turpin JA, Jiménez-Olmedo JM, Penichet-Tomás A, Pueo B. Effectiveness of male handball goalkeepers: A historical overview 19822012. Int J Perf Anal Sports 2016;16(1):143-156. 
5. Ferrari WR. Valente dos Santos JV. Simoes Vaz VP. Offensive process analysis in handball: Identification of game actions that differentiate winning from losing teams. Am J Sports Science 2014;2(4):92-96.

6. Foretić N, Rogulj N, Trninić N. The influence of situation efficiency on the result of a handball match. Sport Science 2010;3(2):45-51.

7. González A, Botejara JL, Martínez I, Chirosa LJ. Effectiveness of the attack and the throw of the first four teams in the men's handball games ODESUR 2014. Educ Fís Cien 2016;18(1):e004.

8. Gutiérrez O, Ruiz JL. Game Performance versus Competitive Performance in the World Championship of Handball 2011. J Hum Kinet 2013;36(1):137-147.

9. Ruiz-Sánchez V, Gómez-López M, Herrera-CuadradoJL. Observational analysis of handball shot in the counterattack phase of the national teams finalists in 2015 Qatar World Handball Cup. Espiral Cuad Prof 2017;10(20):73-79.

10. Sáez FJ, Roldán A, Feu S. Difference in the statistics of game between the winning and losing teams of the king's cup 2008 of male handball. E-balonmano.com: J Sport Science 2009;5(3):107-114.

11. Antúnez A, Ureña F, Velandrino AP, García MM. Value of the efficiency of intercept with success of the goalkeeper of handball before the launching after the aplication of a perceptive program-motor. Rev Int Med Cienc Ac 2004;4(15):192-203.

12. Muñoz A, Martín E, Lorenzo J, Rivilla J. Analysis of different training models for handball goalkeepers. E-balonmano.com: J Sport Science 2012;8(3):223-232.

13. Pascual X, Lago C, Casáis L. The influence of the goalkeeper efficiency in handball teams performance. Apunts Educ Fís Deporte 2010;99(1):72-81.

14. Daza G, Andrés A, Tarragó R. Match statistics as predictors of team's performance in elite competitive handball. Rev Int Cienc Deporte 2017;13(48):149-161.

15. González A, Bermúdez S, Martínez I, Chirosa LJ. Goalkeepers'effectiveness in the ODESUR Games and the Pan-American Handball Championship in 2014. Apunts Educ Fís Deporte 2017;(130):95-105.

16. Karastergios A, Skandalis V, Zapartidis I, Hatzimanouil D. Determination of technical actions that differentiate winning from losing teams in women's handball. J Phys Educ Sport 2017;17(3):1966-1969.

17. Hansen C, Sanz-López F, Whiteley R, Popovic N, Ahmed HA, Cardinale M. Performance analysis of male handball goalkeepers at the World Handball championship 2015. Biol Sport 2017;34(4):393-400.

18. Speicher U, Kleinoeder H, Klein GD, Schacck T, Mester J. An analysis of the cognitive action speed of goalkeepers in women's team handball as the basis of a more effective training control. Leistungssport 2006;36(6):2-15.

19. Prudente J. Análise da performance táctico-técnica no Andebol de alto nível: estudo das ações ofensivas com recurso à análise sequencial. $\mathrm{PhD}$ Thesis (Unpublished). University of Madeira. Funchal. 2006.

20. International Handball Federation. Competitions Archive: Men World Championships. International Handball Federation; 2015. Recovered from http:// www. ihf.info/IHFCompetitions/CompetitionsArchive/MenWorld-Championships/ tabid/4861/Default.aspx

21. Antón JL. El modelo de juego en alto nivel en el balonmano de 2005: características, índices y escalas de rendimiento como bases para un modelo de preparación eficaz [The model of high-level play in handball in 2005: characteristics, performance indices and scales as the basis for an efficient preparation model]. Área Balonmano 2005;37:1-9.

22. Meletakos P, Vagenas G, Bayios IA. Multivariate assessment of offensive performance indicators in Men's Handball: Trends and differences in the World Championships. Int J Perf Anal Sports 2011;11(2):284-294.

23. Gutiérrez-Dávila M, Rojas J, Ortega-Becerra M, Párraga J, Campos J. Functional variability as efficiency factor in handball throwing to the goal. E-balonmano.com: J Sport Science 2012;8(2):121-134. 
24. Wagner H, Kainrath S, Müller E. Coordinative and tactical parameters of teamhandball throw. The correlation of level of performance throwing quality and selected technique-tactical parameters. Leistungssport 2008;38(5):35-41.

25. Rivilla-García J, Navarro F, Sampedro J. Influence of the opposition of the goalkeeper on throwing accuracy in senior and u-18 handball players. E-balonmano. com: J Sport Science 2011;7(1):17-25.

26. Blanco $\mathrm{P}$. The observational analysis of performance in the handball 's throwing of the Spanish promises selection. E-balonmano.com: J Sport Science 2012;8(2):83-92.

27. González A, Martínez I. Análisis de la eficacia del contraataque en el Campeonato Panamericano 2008 Adulto Masculino [Analysis of the effectiveness of the counterattack in the 2008 Pan-American Adult Men's Championship]. Rev Universitaria Educ Fís Deporte 2009;(2):4-12.

28. Sáez FJ, García J, Antúnez A, Valle A, Feu S. Differences in performance indicators between u'16 male winners and losers handball teams based on goal difference. E-balonmano.com: J Sport Science 2013;9(1):5-16.

29. Kioumourtzoglou E, Derri V, Tzetzis G, Theodorakis Y. Cognitive, perceptual, and motor abilities in basketball performance. Percept Motor Skill 1998;86(3 Pt 1):771-786.

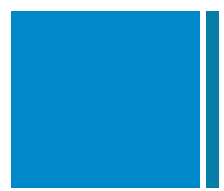

Corresponding author

Manuel Gómez-López

Department of Physical Activity and Sport, Faculty of Sport Sciences

University of Murcia, Santiago de la Ribera, 30720 Murcia, Spain

Email: mgomezlop@um.es 